\title{
整
}

\section{Hans Küng se voorstel vir 'n eietydse etiek}

\author{
S.A. Strauss \\ Departement Dogmatologie \\ Universiteit van die Vrystaat \\ BLOEMFONTEIN
}

E-pos: sstrauss@iafrica.com

Abstract

Hans Küng's proposal for contemporary ethics

This contribution undertakes a critical assessment of the well-known Hans Kün's proposal for contemporary ethics in his book Global responsibility. In search of a new world ethic (1990). This article commences by providing some background on this publication as well as on the theology of Kung in general. The content of the book is then paraphrased in summarised form. The last part of the article analyses four major convictions of Küng, against which the Reformed doctrine is brought forward. These convictions deal with the ethical aspects of normativity, humanity, postmodernity and ecumenicity.

\section{Inleiding}

Hierdie studie word opgedra aan 'n gewaardeerde kollega en geesgenoot, prof Paul de Bruyn. Omdat De Bruyn grotendeels etiek en apologetiek gedoseer het, is daar na 'n tema gesoek waar hierdie twee ondersoekvelde min of meer gekombineer word. Die keuse het geval op 'n redelik onlangse publikasie van die internasionaal bekende teoloog Hans Küng: Projekt Weltethos, en wat daarmee in verband staan. Hierdie werk uit 1990 is spoedig in Engels vertaal onder die titel Global responsibility. In search of a new world ethic (1991). Ter wille van makliker toeganklikheid word in hierdie bydrae uit die vertaling aangehaal.

Soos die oorspronklike Duitse titel suggereer, gaan dit vir Küng in hierdie publikasie om aspekte van 'n navorsingsprojek waarmee hy hom die afgelope aantal jare besig hou. Dié projek het hoofsaaklik 'n omvattende en vergelykende studie van die groot wêreldgodsdienste op die oog. Küng werk daarin met die hipotese dat daar geen wêreldvrede sonder vrede tussen die godsdienste kan bestaan nie. Intussen het die onderhawige publikasie soveel belangstelling uitgelok dat die sogenaamde Parlement van Wêreldgodsdienste in 1993 in 
Chicago 'n "Declaration toward a global ethic" uitgevaardig het. Daarin word andermaal die hoofsake uit Global responsibility beklemtoon. Küng se teologie is dus geen studeerkameraangeleentheid nie, maar het reeds sy invloed in die hedendaagse samelewing laat geld. 'n Bewys daarvan word gelewer op grond van die feit dat 'n groot aantal beroemde en invloedryke figure uit die geledere van staatkundiges, die Judaïsme, die Christendom, die Islam en die Oosterse godsdienste op sy uitnodiging skriftelik op die "Declaration" gereageer het. Küng het die "Declaration", tesame met die reaksies daarop en 'n belangrike inleiding uit sy eie pen in 1996 uitgegee onder die titel (vertaal) Yes to a global ethic. Selfs dit was nog nie die einde van die program wat met Global responsibility begin het nie. Küng het verder gegaan en self sy teologiese insigte in terme van die hedendaagse wêreldwye politiek en ekonomie uitgespel. Ongelukkig is dié nuutste werk, A global ethic for global politics and economics (1997), tans nog nie in Suid-Afrika beskikbaar nie.

Die doelstelling van hierdie artikel is dan 'n bestudering van Hans Küng se voorstel vir 'n eietydse etiek. Dat dié etiese tema ook raakvlakke met die apologetiek vertoon, kan soos volg gemotiveer word. Goed beskou, gaan dit in die gereformeerde apologetiek om 'n verdediging van die gereformeerde leer teen die invloed van veral die moderne wysbegeerte op die teologie (vgl. Strauss, 1991:115). Min ander kontemporêre teoloë kan vir dié doel 'n ryker studieveld oplewer as juis Hans Küng! Voordat die eintlike tema aan die orde gestel word, gaan ons, ter wille van 'n goeie agtergrond, eers oorsigtelik die lewe en werk van Küng bekyk. Daarna word Global responsibility agtereenvolgens verkennend bekendgestel en daarna meer grondig ontleed. Die artikel eindig met 'n beoordeling van Küng se voorstel, by name vanuit 'n konfessioneel-gereformeerde gesigspunt. Daarin word dus ook by De Bruyn se ander groot liefde, die gereformeerde simboliek, aangesluit.

Vooraf dan eers iets in die algemeen oor die teoloog Hans Küng (geb. 1928) en sy teologie. As 'n mens die teologie van die afgelope vier dekades wil bestudeer, dien Küng as 'n handige invalspoort. Jeanrond (1997:162) stel onomwonde dat geen ander teoloog in ons tyd soveel soos Küng gepubliseer, vertaal en gelees is nie. 'n Mens sou hom as 'n regte "branderplank-teoloog" kon bestempel: hy stel hom ten doel om elke nuwe teologiese golf wat aanrol te bestyg en sover as moontlik op die kruin daarvan te ry! Küng is veral handig omdat hy ander eietydse denkers se gedagterigtings intelligent saamvat, en elke keer op die voorpunt van die nuutste ontwikkeling beweeg.

Toe hy in 1957 gedoktoreer het, het hy sy proefskrif geskryf oor 'n destydse aktuele tema, Karl Barth se regverdigingsleer. Vanweë sy ekumeniese ingesteldheid vervul hy daarna 'n belangrike funksie tydens die Tweede Vatikaanse Konsilie (1962-1965). Nadat hy professor aan die Katolieke Fakulteit Teologie in Tübingen geword het, spreek hy sulke ernstige bedenkinge uit teen die 
onfeilbaarheid van die Pous dat hy uiteindelik, ná jare van omstredenheid, sy kerklike pos moes ontruim. Hy bly egter hoof van die onafhanklike Instituut vir Ekumeniese Navorsing aan dieselfde universiteit. In hierdie hoedanigheid het hy deur die jare op 'n besondere manier aan die internasionale teologiese debat deelgeneem.

Küng se teologiese ontwikkeling kan breedweg in vier periodes ingedeel word (vgl. Jeanrond, 1997:163 e.v. vir volledige besonderhede). Die eerste periode word gekenmerk deur 'n toegespitste aandag op die leer van die kerk, en duur tot ongeveer 1970. In die tweede periode (gedurende die dekade '70) hou hy hom met die vernaamste loci van die dogmatiek besig, soos sy omvattende boeke oor die Godsleer, die Christologie en die ewige lewe getuig. Veral sy On being a Christıan (1976) uit dié tydperk bevat reeds belangrike etiese grondlyne wat later in Global responsibility weer voortgesit word: sake soos die normatiwiteit en die eiesoortigheid van Christelike geloof en gedrag. Küng se derde periode (min of meer die dekade ' 80 ) word weer eens deur die toe heersende aktuele temas beheers: die metodologiese grondslae van die teologie, en die verhouding tussen die Christelike en ander godsdienste. Veral sy Theology for the third millennium (1988) asook die versamelwerk wat hy saam met die welbekende Amerikaanse teoloog, David Tracy, uitgegee het, Paradigm change in theology (1989), bring 'n nuwe kontemporêre tema, die postmoderne benadering, sterk na vore. Ook dit speel 'n belangrike rol in Global responsibility, wat 'n jaar of wat later sou verskyn. Die vierde fase, vanaf 1990 , word deur Küng se huidige navorsingsprojekte oor etiese kwessies en die wêreldgodsdienste in beslag geneem. Weer eens is dié temas tans nie net sy persoonlike belangstelling nie; hulle verteenwoordig juis die nuutste tendense in die teologie, en is as sodanig kenmerkend van die tydsgees van hierdie laaste dekade van ons eeu. Om Küng te bestudeer hou dus ' $n$ ekstra beloning in: die navorser leer die eie tyd deeglik ken - die jongste brander wat tans strand toe spoel. Of óns hierdie brander óók gaan ry, sal eers aan die einde van ons ondersoek vasgestel kan word.

\section{Verkenning}

In hierdie paragraaf word 'n poging aangewend om die inhoud van Hans Küng se Global responsibility' so oorsigtelik as moontlik aan te bied. Die outeur self maak dit vir ons maklik wanneer hy reeds in die inleiding kortliks uitspel waarom dit eintlik vir hom met dié publikasie gaan (xv). Dit gaan naamlik om drie sake, wat terselfdertyd as die drie hoofindelings van die boek dien:

- Geen oorlewing sonder 'n wêreldwye etiek nie.

- Geen wêreldvrede sonder godsdiensvrede nie.

I Bladsynommers tussen hakies verwys in die verdere bespreking na Global responsibility. 
- Geen godsdiensvrede sonder dialoog tussen die godsdienste nie.

Nog korter gesê dus: etiek, vrede, dialoog.

\subsection{Geen oorlewing sonder 'n wêreldwye etiek nie}

Die eerste hoofdeel van die boek, "No survival without a world ethic", dra as subtitel: "Why we need a global ethic". Hieronder tref ons 'n belangrike gedeelte oor postmoderniteit aan (2-24). Küng se ontleding van die huidige wêreldpolitiek lei hom tot die oortuiging dat ons tans die einde van 'n era beleef. Sowel die Weste as die Ooste openbaar 'n morele krisis. Ons tyd word gekenmerk deur 'n wantroue in die (moderne) ideologie van vooruitgang; daar word gesoek na 'n nuwe "makroparadigma" (19), 'n denkpatroon wat die tradisionele tweespalt van kommunisme en kapitalisme te bowe kan gaan. Dié behoefte word juis deur die huidige wêreldwye opkoms van die postmoderne benadering aangespreek. Maar dan moet postmoderniteit goed begryp word - nie as kontra- of ultra-moderniteit nie, maar as iets wat moderniteit kan transendeer en vervang (22).

In 'n volgende afdeling van die eerste gedeelte bespreek Küng die noodsaaklikheid van universeel erkende, bindende etiese waardes en norme vir die bereiking van die ideaal van wêreldurede (25). Hy is van mening dat enige demokrasie 'n basiese etiese konsensus vereis (27). Dit vind hy in die slagspreuk: "planetary responsibility" (29). Die hele mensdom moet vandag opgeroep word om verantwoordelikheid te aanvaar, veral vir ander mense. In plaas van die modernisme wat etiek as 'n privaat aangeleentheid beskou het, moet ons in die postmoderne era van etiek weer 'n saak van openbare belang maak. Samevattend laat hy in dié verband hoor: "The undivided world increasingly needs an undivided ethic. Postmodern men and women need common values, goals, ideals, visions" (35). En, voeg hy daaraan toe, dit veronderstel 'n religieuse oriëntasie, niks minder nie as geloof. Maar omdat ons wêreld vandag uit 'n pluraliteit van gelowe bestaan, sal ons 'n koalisie van gelowiges en ongelowiges moet nastreef (36).

Küng is daarvan oortuig dat die moderne vertroue op die wetenskap nie aan ons die verlangde bindende etiese norme kan verskaf nie (42). Waar moet ons hulle dan vandaan haal? Uit die godsdiens, iets wat homself juis in ons postmoderne tyd met ' $n$ sekere weerbarstigheid weer aan ons opdring as 'n universele menslike verskynsel (44). Uit die aard van die saak, besef Küng, sal die verskillende godsdienste natuurlik dikwels verskillende etiese voorskrifte propageer. Maar dié probleem kan oorbrug word indien ons almal sal besef dat alle etiese riglyne nie net so uit die hemel geval het nie, maar dat hulle hier op aarde geformuleer is. En in daardie proses van formulering speel die menslike outonomie, sy ervaring en sy rede, 'n deurslaggewende rol (48 e.v.). 
Juis op hierdie punt ontstaan daar egter weer 'n probleem. Hoe kan ons sulke etiese norme, wat so menslik is, onvoorwaardelik navolg? In Engels gestel: "Can what is humanly conditioned be an unconditional obligation?" (51). Om vir ons 'n "kategoriese imperatief" te kan wees, móet etiese voorskrifte gefundeer wees op "an Absolute", waarvan Küng sê:: "That can only be the ultimate, supreme reality, which while it cannot be proved rationally, can be accepted in a rational trust regardless of how it is named, understood and interpreted in the different religions" (53). In hierdie opsig het alle egte godsdiens die vermoë om die menslike bestaan ten goede te verander: dit bring 'n diepte-dimensie na vore, dit gee sin aan die lewe, selfs in die aangesig van die dood, en so meer. Wat dit veral kan doen, is dit: "Religion can guarantee supreme values, unconditional norms, the deepest motivations and the highest ideals: the why and wherefore of our responsibility" (54). Dit is juis hierdie opregte godsdienstigheid wat, na Küng se mening, in ons postmoderne periode nuwe geleenthede gebied word.

Ten spyte van die etiese verskille tussen die verskillende groot wêreldgodsdienste, is Küng daarvan oortuig dat daar genoeg gemeenskaplik tussen hulle bestaan om een wêreldwye etiek op te grond. Hy noem ses sulke perspektiewe (56 e.v.):

- almal strewe na menslike welsyn;

- almal strewe dieselfde doelstellings van basiese menslikheid na, byvoorbeeld om nie te moor, te steel, te lieg en onsedelik te wees nie;

- almal streef 'n redelike middeweg tussen libertinisme en legalisme na;

- almal handhaaf die goue reël van ander behandel soos jyself behandel wil word;

- almal motiveer, ook vandag nog, mense tot 'n morele lewenswyse;

- almal gee sin aan mense se aardse bestaan, veral in die lig van een of ander toekomsverwagting.

Nie net hierdie algemene waardes nie, maar ook elke godsdiens se besondere, eiesoortige benadering sal 'n bydrae tot 'n wêreldwye etiek kan lewer (60).

Küng beskou die Baselse Verklaring oor "Justice, peace and the integrity of creation" in 1989 as 'n model van die spesifieke bydrae wat die Christelike godsdiens tot die postmoderne periode kan lewer (65). Hy wys veral op daardie gedeelte van die Verklaring wat dit toejuig dat 200 jaar na die Franse Revolusie daar in Europa vandag byna algemene konsensus bestaan, in state sowel as kerke, oor die moderne uitgangspunte van destyds: menslike outonomie, vryheid, gelykheid en solidariteit (66) Aansluitend daarby, veral met die oog op die vereistes wat postmoderniteit tans aan ons stel, vul Küng dié uitgangspunte soos volg aan (67 e.v.): "not just freedom, but also justice; not just equality, but also plurality; 
not just brotherhood, but also sisterhood; not just coexistence, but also peace; not just productivity, but solidarity with the environment; not just toleration, but ecumenism". Ons "global responsibility" lê presies in die nastrewing van hiérdie ideale!

\subsection{Geen wêreldvrede sonder godsdiensvrede nie}

Die tweede hoofdeel van die boek dra die titel "No world peace without religious peace", en die subtitel "An ecumenical way between fanaticism for truth and forgetfulness of truth" (71). Hoewel daar talle voorbeelde van godsdiensoorloë in die geskiedenis aangetoon kan word, was dit tog ook in verskeie lande aan die Christelike godsdiens te danke, volgens Küng, dat daar na die Tweede Wêreldoorlog vrede heers (74). Hy meen dat hierdie vredemakende rol van die godsdienste uitgebou kan word, indien daar 'n teologies aanvaarbare weg vir Christene (en ander) gevind kan word om die waarheid van ander godsdienste te erken, sonder om die waarheid van die eie godsdiens prys te gee (78). Die uitweë van 'n absolutistiese eksklusivisme sowel as 'n relativistiese inklusivisme moet afgewys word (80). Daar moet eerder na universele etiese kriteria vir waarheid gesoek word. En dié is te vinde waar die godsdienste daarin geslaag het om die eg menslike, die humanum, doeltreffend teen die agtergrond van die Absolute tot stand te bring (86).

'n Volgende paragraaf word uitdruklik aan die humanum as basiese ekumeniese kriterium gewy (89 e.v.). Dialekties word die standpunt geformuleer: "true humanity is the presupposition for true religion", en "true religion is the fulfilment of true humanity" (91). Aan hierdie kriterium moet alle godsdienste gemeet word. 'n Godsdiens is waar en goed in dié mate wat dit egte menslikheid dien en bevorder.

In die laaste paragraaf van die tweede hoofdeel word eintlik al 'n oorgang na die derde hoofdeel gemaak. Küng bepleit 'n dialoog tussen die godsdienste. Dit moet egter nie met godsdienstige indifferentisme, relativisme en sinkretisme verwar word nie (96). Hy beywer hom vir die handhawing van die waarheid, maar dan in vryheid (97). Dit impliseer vir hom as Christen 'n maksimale teologiese openheid teenoor ander godsdienste. Gesien van die buitekant af, kan meer as een godsdiens "waar" wees, byvoorbeeld daarin dat hulle die menslike bevorder en getrou bly aan hulle eie oorsprong of kanon. Maar gesien van binnekant af, is net die Christelike godsdiens waar, omdat dit die gees van Jesus Christus vertoon (98 e.v.). So, meen Küng, kan 'n intergodsdienstige dialoog gevoer word sonder om die behoud van die eie godsdienstige identiteit prys te gee. In die voer van dialoog lê die epogmakende uitdaging van ons postmoderne tyd - ten minste net so ingrypend as die tyd van Augustinus of Luther (104). 


\subsection{Geen godsdiensvrede sonder dialoog nie}

Die laaste gedeelte van die boek, "No religious peace without religious dialogue", lewer nie eintlik 'n bydrae tot die tema van die etiek wat ons primêr hier besighou nie. Dit is eerder 'n uiteensetting van die metodologiese benadering in Küng se navorsingsprojek oor die godsdienstige situasie van ons tyd. As sodanig bevat dit wel belangrike gegewens aangaande Küng se aanwending van die paradigmateorie (120 e.v.), en sy ideaal van 'n ekumeniese teologie (130 e.v.). Heel aan die einde spel hy enkele praktiese konsekwensies van sy godsdiens-dialogiese benadering uit, byvoorbeeld intergodsdienstige gemengde huwelike asook gesamentlike sosiale projekte, religieuse feesvierings en politieke inisiatiewe.

\section{Ontleding}

Die gegewens in die vorige paragraaf is op sigself genoeg om enige etikus aan te spoor om kommentaar op Hans Küng se prikkelende standpunte te lewer. As die etikus daarby ook 'n apologetiese belangstelling en 'n konfessionele verankering het, word die versoeking om aan die debat deel te neem des te sterker. Voordat so 'n kritiese beoordeling onderneem kan word, moet daar egter sistematies meer orde op sake gestel word. Hierdie paragraaf wil dan die mes 'n bietjie dieper as die oppervlakte insteek en Küng se grondoortuigings punt vir punt probeer blootlê.

\subsection{Normatiwiteit}

Die eerste punt wat ons aandag verdien, is Küng se oortuiging aangaande die normatiwiteit van die etiek. Die hele Global responsibility gaan eintlik oor, wat die skrywer noem, die wêreldwye behoefte aan "universally binding ethic norms" of "global standards" (25). 'n Nuwe wêreldorde benodig 'n wêreldetiek, "a binding and obligatory ethic for the whole of humankind" (34), dit wil sê "common values, goals, ideals, visions" (35). Dieselfde ideaal van universeel geldige etiese norme kom herhaaldelik in wisselende bewoordings in die boek voor, byvoorbeeld: "the common good" (50); "general validity" (51); "the absoluteness and universality of ethical demands" (53).

Die groot vraag is nou: Wat is die bron van hierdie norme? Waar tref ons hulle aan? Ons het reeds verneem dat Küng sê dat etiese norme nie uit die hemel geval het nie, maar hier op aarde deur mense geformuleer word (48). Dit geld vir alle godsdienste, ook vir die Christendom. Etiese norme kan dus, sê hy letterlik, uit geen heilige boek, ook nie uit die Bybel, afgelei word nie (48). Die menslike outonomie, sy hele ervaring ("experience") speel daarvoor 'n te groot rol (49). Trouens, die modeme lewe het gewoon te kompleks geword om etiese norme te probeer vasstel "in a naive blindness to reality" (49). 'n Hedendaagse etiek is afhanklik van kontak met die natuur- en die menswetenskappe (50). 
Twee punte moet nog hierby benadruk word: situasie en outonomiteit. Aangesien die werklikheid, naas die Bybel, klaarblyklik as 'n bron vir etiese norme funksioneer, speel die spesifieke situasie waarin norme gehoorsaam word 'n deurslaggewende rol. Küng probeer weliswaar die eensydigheid van sowel 'n wettiese as 'n situasie-etiek vermy, maar gebruik nogtans uitdrukkings wat baie naby aan 'n situasie-etiek kom ("the situation should govern the norms", 57). Die ander punt is dan outonomiteit. In 'n belangrike paragraaf (51) met 'n belangrike voetnoot (voetnoot 77, p. 151) definieer Küng moraliteit in terme van outonomiteit. Hy sê dat teologiese etiek vandag grootliks outonome etiek, die erkenning van menslike vryheid, as geldig aanvaar het. Wanneer hy handel oor die begronding van etiese eise in "n Absolute" (wat ons God noem!), betoog hy verder: "theonomy is not heteronomy, but the ground, the guarantee and also the limit of human autonomy ..." (53).

\subsection{Humaniteit}

Naas hierdie meer formele aspekte van Küng se etiek moet ons nou, as 'n tweede grondoortuiging by hom, let op die inhoudelike van sy etiek. Dit word aangetref in die begrip humaniteit. In verband met wat hy self die sleutelbegrip in sy boek noem, naamlik verantwoordelikheid (29), sê hy dat die doel en maatstaf van etiek is dat mense meer menslik moet word (31). Volgens hom is menslike welsyn, die bevordering van die humanum, per slot van rekening dit waarna al die wêreldgodsdienste streef (56). Daarom is juis dit ook die kriterium waardeur die waarheid van elke godsdiens vasgestel kan word (85-88). 'n Paragraaf kry selfs die opskrif: "The humanum as a basic ecumenical criterion" (89). Daarin praat hy in soveel woorde van "what is truly human as a universal criterion". Hy spreek die oortuiging uit dat al die godsdienste ten minste oor hierdie basiese vraag na die kriterium sal saamstem (90). Hy durf selfs die stelling aan: "what is human, truly human, what has human dignity, can with justification appeal to the "divine"" (91). Nie dat godsdiens en die humanum aan mekaar gelyk is nie; daar is, soos ons reeds verneem het, 'n wedersydse dialektiese verhouding tussen die twee: "True humanity is the presupposition for true religion", en terselfdertyd: "True religion is the fulfilment of true humanity".

Vanweë Küng se beklemtoning van humaniteit is daar by hom ook 'n opvallende positiewe waardering vir die moderne demokrasie. Wat in sowel die sosialisme as die kapitalisme gewaardeer kan word, is die strewe na demokrasie (5-7). Tweehonderd jaar na die Franse Revolusie kan ons ons vandag daarin verheug dat die demokratiese waardes van outonomie, vryheid, gelykheid en solidariteit deur almal, ook Christene, hoog geag word (66). Gelukkig het die moderne Christendom die menslike waardigheid as 'n oorspronklike Christelike waarde deesdae as't ware herontdek. Daarom kan ons ook die moderne demokratiese verklarings van menseregte van harte onderskryf (86). Nadat die humanum 
homself tydens die Verligting eers van die godsdiens en die kerk geëmansipeer het, kom dit tans - gelukkig! - weer in die sfeer van Christelikheid tuis (87). Die versoening en die vrede wat die hedendaagse demokratiese owerhede tussen byvoorbeeld Frankryk en Duitsland tot stand gebring het, getuig van 'n Christelike gesindheid, sê Küng (75).

\subsection{Postmoderniteit}

As Küng se etiek inhoudelik deur humaniteit gestempel word, kan 'n mens sê die eksterne omgewing waarin hierdie humaniteit hom vandag voltrek die paradigma van postmoderniteit is. Daarin sien hy allerlei positiewe moontlikhede vir godsdiens in die algemeen, en ook vir die Christelike geloof (54). Maar dan moet ons postmoderniteit natuurlik reg verstaan - nie as 'n relativistiese afbreek van alle etiese waardes nie, maar as 'n fundamentele verandering daarvan (20). Postmoderniteit mag ook hoegenaamd nie met 'n terugkeer na pre-moderne waardes verwar word nie (40). Dit moet eerder die moderne opvattings verruim en verdiep. Postmoderniteit vereis derhalwe van ons nie net vryheid nie, maar ook geregtigheid; nie net gelykheid nie, maar ook pluraliteit; en so meer (vgl. die aanhaling uit p. 67 in die vorige paragraaf). Vir Küng is dit juis die postmoderniteit wat ons vandag voor die epogmakende uitdaging stel om dialoog tussen die godsdienste na te streef. As sodanig kan dit syns insiens op een lyn met die ander ingrypende en betekenisvolle oorgange in die kerkgeskiedenis geplaas word: oorgange soos toe die Apologete met die Neo-Platoniese paradigma gekonfronteer is, of Thomas met die Romeins-Germaanse, of die Reformatore met die krisis van die Middeleeuse teologie (104).

\subsection{Ekumenisiteit}

'n Laaste grondoortuiging van Küng wat logies met die voorafgaande vervleg is en daaruit as praktiese konsekwensie voortvloei, is sy ideaal van intergodsdienstige ekumenisiteit. Dit berus op sy diepste oortuigings aangaande God, "the ultimate, supreme reality, which ... can be understood and interpreted in the different religions" (53), sowel as godsdiens, per definisie 'n "universal human phenomenon" (44), of anders gesê: "the common quest for the greater truth, for the mystery of the one and true God, which will only be fully revealed, if God so wills, at the end of history" (137). Op grond hiervan ontdek hy dan gemeenskaplike algemene etiese perspektiewe in die wêreldgodsdienste (56-60). Teologies probeer hy homself oor sy standpunt verantwoord deur te strewe na 'n standpunt wat nóg eksklusivisties, absolutisties, nóg relativisties, indifferentisties is (80). Ook 'n simplistiese sinkretisme word afgewys (96). In die gees van die postmoderne erkenning van pluraliteit word 'n intergodsdienstige dialoog as die enigste begaanbare weg beproef. Die konsekwensies hiervan word uitgespel (100-103), en kan miskien die beste saamgevat word as 'n gesindheid van "optimal loyalty to one's own religious faith and maximal openness to others ..." 
(133). Dit impliseer dat ons byvoorbeeld in die gesprek tussen Christene en Moslems dit volledig ("completely"!) aan die proses van gesprekvoering moet oorlaat wat uiteindelik en finaal oor die verhouding tussen Christus en Mohammed gesê moet word.

\section{Beoordeling}

Om die beoordeling nie te wyd te laat loop nie word twee beperkings aangebring. Eerstens gaan daar slegs gekonsentreer word op die vier grondoortuigings wat in die vorige paragraaf blootgelê is. Tweedens word die beoordeling doelbewus vanuit 'n konfessioneel-gereformeerde oogpunt onderneem, met uitdruklike verwysing na die Drie Formuliere van Eenheid. Allerlei moontlike tersaaklike vakliteratuur word dus buite bespreking gelaat.

\subsection{Tweebronneteorie}

Uit die weergawe van Hans Küng se siening van etiese norme het dit vir ons duidelik geword dat hy vir die vasstelling daarvan met twee bronne werk: die Bybel en die (ervaring van die) werklikheid. Jeanrond $(1997: 171,173)$ kom, na 'n deeglike bespreking van Küng se hele oeuvre, tot dieselfde gevolgtrekking. Hy sê dat Küng 'n "kritiese korrelasie" tussen dié twee handhaaf. Hoe dit ook al sy, 'n mens kan jou nie van die gedagte losmaak dat hierdie tweebronnebenadering verbasend baie op die klassieke Rooms-Katolieke teologie lyk nie. Naas en voorafgaande aan die "bonatuurlike" kennis van God wat die kerk onfeilbaar uit die Skrif en die tradisie aflei, is daar immers ook die "natuurlike" teologie, die algemene waarhede wat deur die menslike rede, selfs sonder besondere openbaring, geken kan word (Heyns \& Jonker, 1974:235).

Uiteraard is daar veel in Küng se voorstel vir 'n eietydse etiek wat op 'n verwantskap met die modeme en selfs die postmoderne paradigmas dui. Dink maar net aan sy voorliefde vir iets soos die menslike outonomiteit of situasieetiek. Ook sy kritiese Skrifbeskouing en sy strewe na universeel geldige, algemeen aanvaarde norme is 'n bewys daarvan. Per slot van rekening is dit egter veral sy tweebronneteorie wat sy etiek vir 'n gereformeerde in beginsel onaanvaarbaar maak. Dit verskil radikaal met wat ons aangaande die Reformatoriese sola Scriptura, ook in etiese sake, bely (vgl. Strauss, 1988:142). Dit is veral in NGB Art. 7 wat die totalitêre en eksklusiewe bewoording 'n mens tref:

Ons glo dat hierdie heilige Skrif die wil van God volkome bevat ... Aangesien die hele wyse waarop God deur ons gedien moet word, daarin breedvoerig beskrywe is ... blyk dit dat die leer daarvan heeltemal volmaak en in alle opsigte volkome is ... dié waarheid (van God) is bo alles - (my kursivering - SAS). 
Ons kan dus, om ons gelóóf ontwil, in die etiek, ook die eietydse etiek geen ander norme as Skriftuurlike norme die deurslag laat gee nie.

'n Mens kan saamstem met die uitgangspunt dat etiese norme op God en in die godsdiens gegrond moet word. Gereformeerdes wil ook hulle etiek "teologies" (in die letterlike sin van die woord) begrond. Maar die manier waarop Küng dit doen, is vir ons onaanvaarbaar. Hy praat nie oor God en die diens aan Hom op grond van wat Hy in sy Woord geopenbaar het nie. Nee, hy beproef 'n natuurlike teologie, waarvolgens hy die bestaan van God op redelike gronde probeer "bewys". Ons moet, byna Kantiaans, "n Absolute" veronderstel om die etiese norme onvoorwaardelik bindend te maak.

\subsection{Menslike maatstaf}

Inhoudelik, so het ons in ons ontleding vasgestel, laat Küng sy etiek deur die begnip humaniteit bepaal. Daarin vind hy by uitstek dié universele norm waaroor alle mense vandag, afgesien van hulle eie godsdienstige oortuigings, behoort te kan saamstem. Die bevordering van die humanum is selfs die maatstaf waaraan die egtheid (of waarheid?) van die verskillende godsdienste gemeet kan word. Op sy beurt lei hierdie grondoortuiging Küng daartoe om homself baie positief uit te spreek oor die moderne demokratiese waardes, veral die erkenning van die menslike waardigheid en menseregte. Vir hom is dié sake sonder meer 'n bewys van egte Christelikheid. 'n Mens sou sy standpunt kernagtig soos volg kan formuleer: die humanum het hom eers van die kerk geëmansipeer, maar nou het die kerk dit gelukkig geaksepteer!

Waar kom iemand soos Küng aan hierdie benadering? Dit kan in 'n sekere sin waarskynlik aan die huidige humanistiese tydsgees toegeskryf word. Inderdaad het die ideaal van die mondige, outonome mens sedert die Verligting tot so 'n mate in groot gedeeltes van die kerk ingedring dat baie kerklidmate vandag die bevordering van humaniteit as sodanig as 'n Christelike deug beskou. Dit is ook nie vreemd dat die tydsgees 'n branderplank-teoloog soos Küng, wat hom uitdruklik ten doel stel om op die voorpunt van heersende opvattings te beweeg, sou beïnvloed nie. 'n Mens sou selfs, saam met Cobb (1993:289-292), kan beweer dat Küng se keuse vir die humanum sy verwantskap eerder met die modernisme as die postmodernisme verraai.

Maar is hier nie nog iets anders op die spel nie? As 'n mens verder hieroor nadink, gaan jou gedagtes onwillekeurig in die rigting van die klassieke RoomsKatolisisme. Kan dit wees dat Küng, wat op soveel punte met die konserwatiewe Katolisisme gebots het, tog ook op 'n wesenlike punt steeds daarmee 'n verwantskap vertoon? In daardie kringe is die radikale verdorwenheid van die mens inmers altyd konsekwent verontagsaam. As gevolg van 'n taamlik optimistiese mensbeskouing is daar op 'n semi-Pelagiaanse wyse altyd weggeskram van 
die Skriftuurlike waarheid dat ons "sonder enige verdienste, uit louter genade" (sola gratia!) (HK Son. 23, Vr. 60) gered word. Om dié rede moes die gereformeerde konfessies sterk standpunt inneem om 'n eg Skriftuurlike antropologie te beskerm. Weliswaar is die mens oorspronklik goed en as die beeld van God geskep, word daarin bely. Maar sedert die sondeval is die hele menslike geslag so verdorwe dat hy al sy voortreflike gawes verlóór het (NGB art. 14-15); hy is glad nie meer in staat om iets goeds te doen nie (HK Son. 3); selfs die klein bietjie lig van die natuur wat na die sonde in hom oorgebly het, kan hy nie eers in burgerlike sake reg gebruik nie (DL 3/4,4). Gereformeerdes is dus verplig om 'n veel meer kritiese houding as Küng teenoor die humanum en sy politieke produkte, soos byvoorbeeld die demokrasie, in te neem. Küng se voorstel vir 'n eietydse etiek kan in hierdie opsig dus nie as 'n navolgenswaardige voorbeeld beskou word nie. Dit dien eerder as 'n waarskuwing dat die Christendom uiters versigtig moet wees om nie kontemporêre ideologieë so lank te tolereer dat dit naderhand as dogma gepromulgeer word nie. Dié gevaar het beslis nie net in die Middeleeue (bv. Aristoteles se filosofiese godsbegrip) gedreig nie; dit is in elke geslag, ook ons s'n (humanum), springlewendig.

\subsection{Postmoderne paradigma}

Op 'n meer waarderende noot kan voorts opgemerk word dat Hans Küng baanbrekerswerk verrig het toe hy ons oë oopgemaak het vir die postmoderne paradigma waarin ons ons tans bevind. Inderdaad bied dié benadering nuwe moontlikhede vir die erkenning van die invloed van godsdiens en geloof, wanneer die modernistiese en positivistiese wetenskapsideaal van objektiewe feitelikheid gekritiseer word - solank dit net in gedagte gehou word dat postmoderniteit op meer as een manier verstaan kan word - wat Küng inderdaad ook doen. Tereg distansieer hy hom van 'n totaal relativistiese etiek, soos dit deur sommige ondersteuners van die postmodernisme voorgestaan word.

Ook as gereformeerdes moet ons onsself steeds in 'n solidêr-kritiese gesprek met ons filosofiese omgewing apologeties verantwoord. Dit hang saam met ons belydenis dat ons almagtige God en Vader in sy voorsienigheid om Christus ontwil tye en geleenthede in die geskiedenis bepaal (vgl. HK Son. 10). Dat die modernisme waarskynlik in ons tyd deur die postmodernisme vervang gaan word, is nie 'n ramp nie, maar ook nie noodwendig 'n seën nie. Net soos die bekende Herman Bavinck homself in sy tyd deeglik en gebalanseerd rekenskap gegee het van sy houding teenoor die destyds heersende modernisme, sal ons vandag die postmodernisme positief en negatief moet evalueer (vgl. Strauss, 1998).

\subsection{Ekumeniese dialoog}

Wat, ten slotte, Küng se ideaal van intergodsdienstige ekumenisiteit betref, moet daarteen weer eens kritiek uitgespreek word. Dit val die leser op dat Küng nie 
regtig daarin slaag om 'n teologiese begronding daarvoor uit te werk nie. Ons het tot die gevolgtrekking gekom dat dié ideaal van hom ten diepste op sy siening van God en van godsdiens berus. Maar in albei dié gevalle gaan Küng meer filosofies as streng teologies te werk, en dan nogal meer modernisties as postmodernisties. Hy beskryf God naamlik in terme van " $n$ " Absolute, "the ultimate, supreme reality", en so meer. Godsdiens is vir hom in fenomenologiese sin 'n algemene, menslike verskynsel. Weer eens vertoon sy redenasie dus die kenmerke van 'n natuurlike teologie.

'n Mens kan waardering daarvoor betuig dat Küng in sy ywer vir 'n intergodsdienstige dialoog die slaggate van relativisme en sinkretisme probeer vermy. Of hy egter daarin slaag, is te betwyfel. Juis omdat hy nêrens die uniekheid van God en van die enigste Middelaar, Jesus Christus, Bybels-eksegeties bespreek nie, kom die praktiese konsekwensies van sy standpunt naby aan 'n verloëning van Christus. Waarom formuleer hy uitdruklik "optimaal getrou aan jou eie geloof, en maksimaal oop teenoor die ander"? Kan dié stelling ook omgekeer word, of sal dit dan vir Küng se gevoel te min ruimte vir 'n egte dialoog laat? Naas die sola Scriptura en sola gratia waarna hierbo reeds verwys is, moet 'n derde Reformatoriese solisme hier teenoor Hans Küng gestel word, naamlik solus Christus. Ons Christelike leerboek (HK Son. 11) leer ons om op grond van die Skrif te bely: Jesus verlos ons van al ons sonde, en daar is by niemand anders enige saligheid te soek of te kry nie. Slegs een van twee dinge is immers moontlik: óf Jesus is nie 'n volkome Verlosser nie, of in Hom het ons alles wat vir ons saligheid nodig is.

Om ons te help om in ons veelbewoë tyd werklik navolgers van dié Here te wees, vereis na alle waarskynlikheid 'n ander voorstel vir 'n eietydse etiek as wat Hans Küng ons bied.

\section{Literatuurlys}

COBB, John B. 1993 Inter-religious dialogue, world ethics and the problem of the Humamum. (In Kuschel, Karl-Josef \& Hermann Haring ed. Hans Küng - New horizons for faith and thought London : SCM p 283-293)

FORD, David F. ed 1997. The modern theologians. An introduction to Christian theology in the twentieth century. Second edition. Oxford : Blackwell

HEYNS, J A \& JONKER, W.D. 1974. Op weg met die teologie. Pretoria : NGKB

JEANROND, Werner G 1997. Hans Kung. (In Ford, David F. ed. The modern theologians. An introduction to Christian theology in the twentieth century. Second edition. Oxford Blackwell. p. 162-178)

KUNG, Hans 1976. On being a Christian. Glasgow : Collins. (Oorspronklike titel: 1974. Christ sein. Munchen : Piper.)

KUNG, Hans 1988 Theology for the third millennium. An ecumenical view. New York Doubleday. (Oorspronklike titel: 1987 Theologie im Aufbruch. Munchen : Piper.)

KUNNG, Hans. 1991 Global responsibility. In search of a new world ethic. London : SCM. (Oorspronklike titel: 1990 Projekt Weltethos. Munchen : Piper) 
KUNG, Hans., ed. 1996. Yes to a global ethic. London : SCM. (Oorspronklike titel: 1995. Ja zum Weltethos. Perspektiven für die Suche nach Orientierung. Munchen : Piper.)

KUNG, Hans. 1997. A global ethic for global politics and economics. London : SCM.

KUNG, Hans \& DAVID, Tracy. eds. 1989. Paradigm change in theology. A symposium for the future Edinburgh : Clark.

STRAUSS, S A 1988. Riglyne vir die etiek in die Drie Formuliere van Eenheid. (In De Bruyn, P.J. red. Waar die paaie saamwoon. [Opgedra aan prof. P.W. Buys] Potchefstroom PTP. p. 131-148.)

STRAUSS, S.A. 1991. Inleiding in die dogmatologie. Tydskrif vir Christelike Wetenskap, 27(3): 101-119.

STRAUSS, S.A. 1998. Gereformeerde teologie tussen modernisme en postmodernisme. Tydskrif vir Christelike Wetenskap. Spesiale uitgawe (April 1998): Moderne en postmoderne wetenskapsbeoefening: die moontlikheid van 'n Christelike perspektief as alternatief. p. 95-106. 